\title{
POLITICAL CHRISTIANITY IN ACTION: THE CRUSADES OF AGNES MAUDE ROYDEN
}

\section{$B Y$ ARTHUR DOWNING}

Mr. Downing is a Reference Librarian at the Kilmer Area Library, Rutgers University

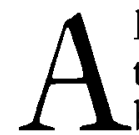

lthough her name may sound unfamiliar to us today, less than fifty years ago Agnes Maude Royden was renowned both in the United States and Great Britain as a fiercely dedicated social reformer. The Church of England provided the forum for Royden's campaigns; her pioneering role as an Anglican preacher symbolized the entry of women into the serious, worldly spheres of religion, politics and economics. From the pulpit she initiated public debate over such volatile issues as disarmament, women's suffrage, labor organization, venereal disease, independence for Ireland, the rights of prostitutes and women in the clergy.

Fortunately, the significance of Royden's activities was recognized in the early I920's by John Boynton Kaiser, then Director of the Public Library in Oakland, California. Inspired by Royden's philosophy Kaiser gathered and inventoried a significant portion of her work. The product of his efforts is a collection of 20 monographs, 6o pamphlets, newspaper clippings, photographs and other memorabilia capturing not only Royden's original thoughts, but also the public sentiment toward her crusades.

By I 943 Kaiser had moved to New Jersey in order to serve as Director of the Newark Public Library, a position he held until I 958 . In 1962 as he was preparing to retire Kaiser donated many of his personal and professional papers to the New Jersey State Library, which offered some of this material to Rutgers University. (Kaiser had taught Library Science at Rutgers from I 950 to 1957.) The Royden Collection was included in the material transferred to Rutgers. Because of Royden's important contributions to the Women's Movement, the collection was assigned to the Mabel Smith Douglass Library, where it remains today.

Although Royden's life would be dedicated to aiding the homeless, the unemployed and the victims of war and economic inequity, she was born in 1876 to very comfortable surroundings. Her father, Sir Thomas Royden, was a wealthy shipowner and baronet. Royden 


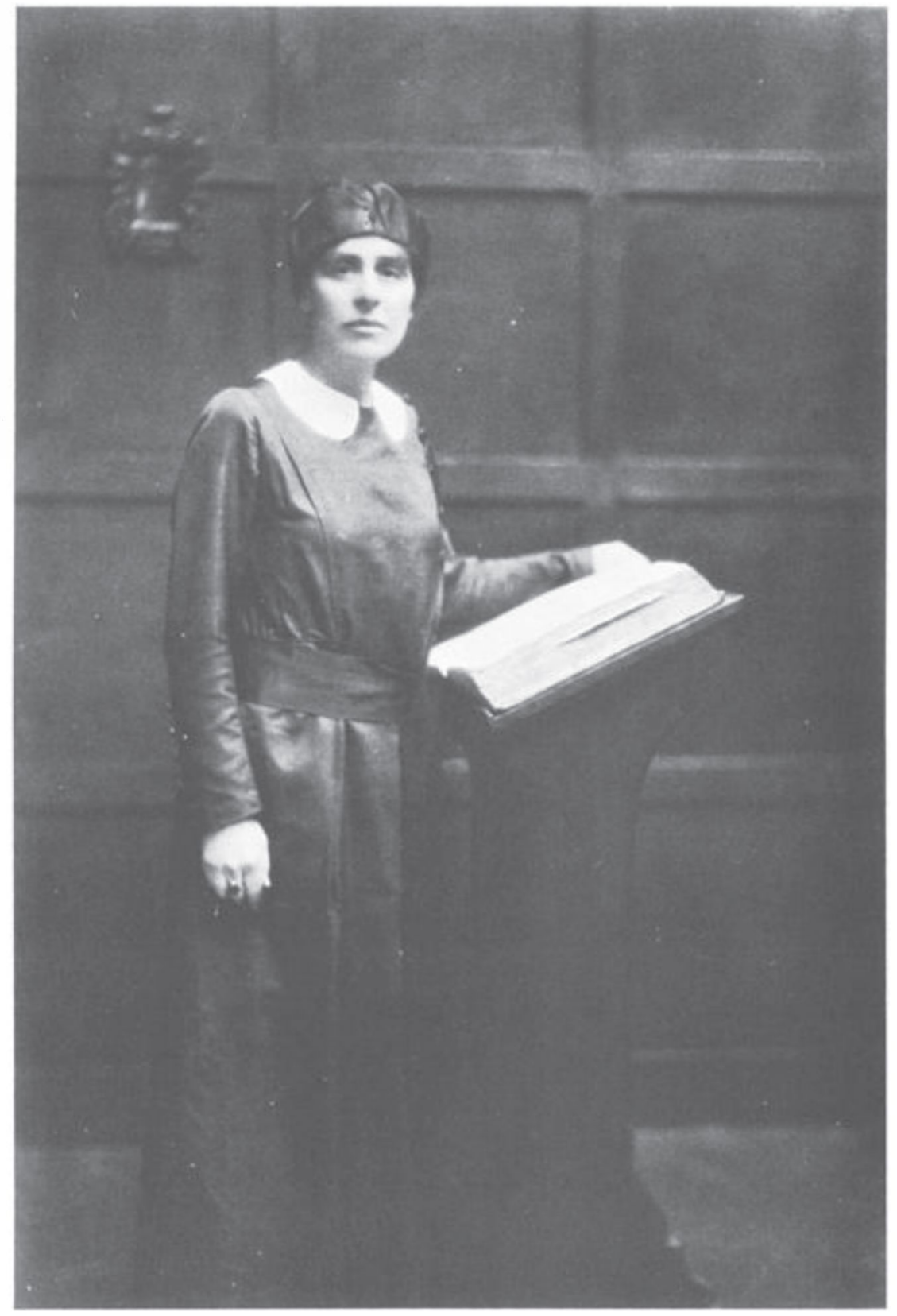

AGNES MAUDE ROYDEN

(MABEL SMITH DOUGLASS LIBRARY, RUTGERS UNIVERSITY) 
received her education at Chelthenham Ladies' College and Lady Margaret Hall, Oxford. Shortly after graduation in I 899 Royden was employed as a social worker at the Victoria Women's Settlement in Liverpool. Three years later she became a parish worker and began teaching through the Oxford University extension delegacy. It is during this period that Royden developed her talents as a public speaker-talents which were first demonstrated in her struggle for women's rights.

Royden's formal participation in the Women's Movement began in 1908 with her membership in the National Union of Women's Suffrage Societies (NUWSS). In its pursuit of enfranchisement for women the NUWSS concentrated on lobbying Parliament, sponsoring rallies and letter-writing campaigns and other constitutional methods rather than the extreme, sensationalistic deeds of its radical counterpart, the Women's Social and Political Union. Royden served on the executive committee of the NUWSS and edited its journal, The Common Cause, from I 9 I 2 to I 9 I 4.

Among the goals Royden sought to achieve through the NUWSS was a guarantee of equal employment opportunities for women. Around the turn of the twentieth century a debate flared in England over the passage of additional Factory Acts, legislation intended to protect the health and safety of factory workers. Since 1802 regulations of this type had been in effect and had dealt primarily with the length of a workday for women and children in different industries. Proponents of the Acts claimed that these regulations had to be confined to women and children in order to minimize the opposition of laissez-faire businessmen, who would surely not allow the government to restrict the freedom of male workers to contract. Despite her own commitment to the relief of the poor, Royden felt compelled to lobby against the Acts, because she believed the restrictions therein: I) served to bar women from employment in certain professions, 2) were imposed unjustly since women were not represented in Parliament.

Consequently, Royden also became a vigorous campaigner for women's suffrage. She argued that the cure for economic and social inequality lay in the proper exercise of political power. Members of Parliament made assurances that they acted in the best interests of both men and women: the enfranchisement of the latter would certainly provide legislators with greater incentive to fulfill such 
promises. According to Royden women lacked sufficient political leverage to guarantee protection of their rights. "They may be legislated out of their work in sheer light-hearted sentimentality by men who have never taken the trouble to understand the industry in question."

Royden campaigned to secure political rights for women with arguments based on morality and ethics. She believed the question of equality was not simply a matter of sex; it was rooted in the same exploitative drive which leads the rich to oppress the poor and one race to enslave another. At the heart of the Women's Movement she saw, not a struggle for the right to vote or for equal wages, but a deep-seated resentment on the part of women against being treated as servants under the direction of benign, omniscient masters. "You know how very convenient it is when there is a class of people to whom you may delegate the work that you do not want to do yourself, with the comfortable conviction that it is all they are fit for." 2 For this reason she anticipated and understood the hostility which faced women like herself, who jeopardized the established division of economic, political and social privileges by seeking achievement outside the walls of a home.

At every opportunity Royden assailed the injustices she associated with rigid sex role assignments, but never as controversially as when she broached the subject of prostitution. "It is the ultimate instance of exploitation. There is nothing comparable to it in the history of the world." 3 Royden argued that a male-dominated society had created two distinct classes of women: the childbearers, whose chastity had to be guarded, and the outcasts, who were damned as immoral, but whose vice was necessary to satisfy the sexuality of men, who were not governed by the code of continence reserved for women. Thus, a society which condemned prostitutes for their deplorable behavior required the existence of such a class of women to preserve the health of the male population as well as the virtue of respectable women. Society compounded this hypocrisy by teaching women to regard members of their own sex as sub-human

' Agnes Maude Royden (AMR hereafter), "Votes and Wages: How Women's Suffrage Will Improve the Economic Position of Women" (London: NUWSS, I9I I), p. I I.

"AMR, "Equality in the Spiritual World" (London: League of the Church Militant, I922), p. 3 .

3 AMR, Women and the Sovereign State (London: Headley Bros., 1917), p. 53. 
creatures worthy of hatred and disgust. Royden pointed out that wives who contracted venereal disease frequently vented their anger solely toward prostitutes, not the husbands who had directly infected them. Many women afflicted with venereal disease were not even informed of the reason for their illness, but were kept in suffering ignorance to prevent them from any exposure to the dark world of prostitution and to conceal the responsibility of their guilty husbands. "Between the wife and the prostitute men have dug a mighty chasm. Since the virtue which was essential to one was impossible to the other-yet both were women-it is obviously expedient to prevent them from corrupting each other." 4 While these two worlds existed side-by-side only men could pass between them. An equally exploitative legal system reinforced the double standard by punishing prostitutes, but not the men who shared in their criminal vice.

As the incidence of venereal disease increased significantly in Great Britain at the end of World War I public attention focused on methods of curtailing prostitution. Much of the momentum behind this concern was provided by the Women's Movement, therefore Royden initially expected a genuine solution to be found. Her optimism soon faded as public interest produced only captivating news items. "The good intentions of the man (and woman) in the street were equalled or even surpassed by his profound ignorance of the problem with which he proposed to deal." 5 To ignorance she attributed a movement for the reinstitution of the Contagious Diseases Acts of 1 864-I 869. This series of legislation was designed to regulate prostitution by permitting police in military areas to forcibly subject suspected prostitutes to medical examinations. Women who refused an examination were imprisoned; those who complied forfeited their reputations.

Once again Royden lamented how easily women could be deprived of their basic human dignity, simply because they were suspected of being prostitutes-women considered to be less than human. She drew from her personal experience as a social worker and the investigations of other social researchers to argue that prostitution was not caused by an innate moral deficiency, but rather by economic and social conditions ripe for reform. Poverty, over-

4 Ibid, pp. 58-59.

5 AMR, in her foreword to Downward Paths: An Inquiry into the Causes Which Contribute to the Making of a Prostitute (London: G. Bell and Sons, 1917), p. viii. 
crowded homes and child abuse were cited as the chief determinants. Royden suggested that instead of turning to panic legislation those concerned about prostitution should strive to guarantee working women an environment which nurtures their human spirit and decent wages which do not require physical exhaustion.

Royden scored an impressive victory against state-sanctioned prostitution in I9 I 8 when, as an assistant preacher at the Guild House in London, she repeatedly denounced the maintenance of the Maisons Tolerées-medically supervised houses of prostitution within the bounds of the British Army. The idea that the government would act as a procurer for soldiers demonstrated to Royden how low the morals of a nation will descend during a war. The knowledge that certain ministers had actually defended the practice only intensified her disgust. Royden was characteristically frank in her attack: "To any woman who believed the sacrifice to be necessary, I would say that she ought herself to volunteer! The men who urge regulated prostitution on the grounds of national necessity ought to invite their wives and daughters to fill the places left vacant by the women who are worn out!"6 The British government quickly succumbed to the public outrage generated by Royden's protests, and the system was abolished.

The cornerstone of Royden's commitment to women's rights was her belief in the spiritual equality of men and women, or, restated in more theological terms, the belief that "men and women are of equal value in the sight of God." 7 To support this claim she pointed to the absence in Christ's teachings of any special duties, virtues or vices attributed exclusively to one sex. According to Royden $\mathrm{He}$ required the same moral standard from men as from women and made the same demand on their intelligence. "When I think how Christians ... have assigned the virtues of strength and courage and self-reliance and authority and dignity and magnanimity to men, and to women has been more favourably commended the virtues of unselfishness and humility and submission and endurance, and all those virtues for which men give women so much scope in ordinary life, I marvel where they got their authority." 8 Royden

\footnotetext{
${ }^{6}$ Quoted by Joseph Fort Newton in "Maude Royden: The Story of a Great Woman's Great Opportunity," The Century Magazine, March I928, pp. 566-567.

7 AMR, "Equality in the Spiritual World," p. 2.

${ }^{8}$ Ibid, p. 5 .
} 
asserted that, if Christ's teachings were isolated from their Scriptural contexts, one could not distinguish whether $\mathrm{He}$ was addressing men or women. She added, however, that by understanding the special life experiences of women and fashioning His parables around the activities of the home, Christ instilled His principles with particular appeal and significance to women.

Although Royden found no basis for sexual inequality in the Scriptural foundation of Christianity, she detected it in the structure and practices of the Anglican Church. Few positions of responsibility were entrusted to women while men routinely performed duties ranging from the collection of offerings from the congregation to service on Church governing bodies. The shortage of men during the First World War had forced many churches to accept women in essential functions, at times with the condition that they remain unseen by the congregation or that they maintain an acceptable distance from the altar. Some ministers believed these precautions were necessary to prevent men from becoming sexually aroused during religious services; others merely considered women unworthy of participation in sacred ceremonies. "It is not service but exploitation that is the rule of this world, and exploitation is the lot of those we regard as our inferiors. If the church illustrates and emphasizes that inferiority in her worship, her practice, her organization, is it not true to say that she is doing her best to perpetuate the sexual exploitation of women by men."9

The role of women within the church was an issue of personal concern to Royden, for at one time she desired ordination as an Anglican minister - an honor which was, of course, beyond reach due to her sex. Her own involvement in the church began with parish relief work and service as a lay reader during the War. In I 9 I 7 she became an assistant preacher at the City Temple, known as London's "Cathedral of Nonconformity." Never before in England had a woman been designated as a regular assistant for the pulpit of a large city. Even the liberal congregation of the City Temple was apprehensive about her appointment, but they immediately accepted her and she developed a large, loyal following.

In I919 Royden was asked by the Reverend Hudson Shaw to preach Good Friday services at St. Botolph's in London. Although

9 AMR, "The Ministry of Women," The Guildhouse Monthly, Feb. 1929, p. 40. 
she accepted the invitation, she never delivered her address, because Bishop Winnington-Ingram asked her to wait until an upcoming conference clearly established church policy regarding the participation of women in religious services. The Lambeth Conference on the Ministry of Women ( 1920) affirmed the ability of women to preach in church during non-statutory services, therefore in 1923 when Royden received a second invitation from St. Botolph's she was enraged by the bishop's decision to once again forbid her acceptance. In her opinion the prohibition stemmed from an inaccurate and oppressively literal interpretation of St. Paul's directive that "women should keep silence in the churches." Io Because the bishop and other members of the church hierarchy construed St. Paul's reference to "churches" as meaning consecrated buildings rather than gatherings of the faithful, Royden had been able to avoid a confrontation in the past by moving her service to a nearby assembly hall. The church's preoccupation with the location of the service was cited by Royden as an indication of the absurd reasoning behind the policy, particularly since no church buildings existed at the time of St. Paul. "There were women standing near the cross when Our Lord was crucified. Is the cross less sacred than the altar? Or the Crucifixion less sacred than the Mass?" "1 After negotiations with the bishop proved ineffective, Royden defied his order and performed the service at St. Botolph's. She and Reverend Shaw were subsequently ostracized by church ministers, who deplored their disobedience and rejected their revolutionary stand on this issue.

Controverting her critics, Royden maintained that she could accept the denial of her right to preach if the reason were her own spiritual or intellectual inadequacy, but denial on the basis of her sex was intolerable. She reasoned that by withholding Holy Orders from women the church was refusing to administer sacred vocations conferred as a blessing from God.

... while the veriest little ragamuffin of a boy may "serve" at the altar, women whom we revere as leaders, reverence as saints, are excluded. We find it a scandal that the most ignorant of young men may get up and admonish us out of the depth of his inexperience and

10 I Corinthians I 4:34 (Revised Standard Edition).

"AMR, "Women and the Church of England" (London: George Allen \& Unwin, Ltd., I9I6), p. 9. 
unwisdom in the pulpit, while women at whose feet the world is willing to sit are treated as though it were a thing impossible that they should have a message from God or know the inspiration of His Spirit. ${ }^{\mathrm{I} 2}$

Royden's dissatisfaction with the Anglican Church led her to leave the City Temple in I 920 and with the help of friends establish an interdenominational group known as the Fellowship Guild. The independence of the Guild allowed Royden to experiment with less traditional services and to regularly preach sermons on sensitive political issues. Despite frequent criticism Royden refused to exclude herself from politics, because she believed that most political questions directly affected the public welfare she felt obliged to safeguard. "The Church of Christ should be concerned with men's bodies as well as their souls and should care when people suffer, not only to bind up their wounds, but to get rid of the cause of trouble." 13 For Royden the remedy for a social ill was frequently a political action. The extent of her intertwining of politics, religion and social reform was made most evident in 1924 by her bold endorsement of the British Labour Party: "I have been convinced that its ideals, its programme and its policy most closely express the spirit of my Master, Christ." ${ }^{4}$ She argued that by refusing to become involved in political debates the Church had divorced itself from the lives and suffering of its people. In her opinion the Church had a responsibility to take a political stand even at the risk of being proved wrong in the future. She wrote, "I think the church, in fear of making a mistake, has ended in making nothing." 15

During the I920's the chief objective of Royden's ministry was helping people cope with the spiritual and physical devastation brought about by the War. Fellow Christians, haunted by memories of unprecedented violence, needed to be reassured of religious fundamentals while famine, disease and other forms of human suffering had to be treated within a world of new economic and political orders. Royden sought to accomplish these goals by preaching a form of Christian socialism in which issues such as unemployment, colonialism and disarmament were analyzed according to models of social justice presented in the Bible. She believed the upheaval

12 Ibid, pp. 9-10.

13 AMR, Political Christianity (New York: G. P. Putnam's Sons, 1923), p. Io.

${ }^{14}$ AMR, "Labour in Office" (London: League of the Church Militant, 1924), pp. I-2.

is AMR, Political Christianity, p. I 5. 
which characterized Europe was due to the tendency of governments to pursue national policies based on hatred and revenge rather than Scriptural guidelines for peace. "And our Lord, looking down upon us must see what ruin we are bringing on our heads, because we will not know the things that belong to peace. . . . Does it belong to peace to try to hold Ireland against her will? Or to force from Germany what Germany cannot pay?"'r6 Unemployment, hunger and disease were all curable, according to Royden, once the government was willing to commit vast sums of money to these problems-money which was being devoted instead to military programs. It outraged Royden that, although Britain had not yet recovered from the $\mathrm{W}$ ar and needed attention paid to its domestic social concerns, millions of pounds were being poured into general rearmaments, an immoral police action in Ireland, and military campaigns in the Middle East and the Soviet Union. "We can always find money for destruction. When you ask for money for human life, then we are told it cannot be found." ${ }^{7}$

Royden had enough insight into global affairs to realize that the combination of economic distress, rising militarism and lingering hostility in Europe would eventually lead to another world war. Thus, the focus of her work shifted to the peace movement and her ministry became more international in scope as she travelled abroad to campaign for peace. By nature Royden was a pacifist; during World War I she joined the pacifist efforts of various religious organizations and the NUWSS. At that time she believed the actions of conscientious objectors could be considered the "moral equivalent" of the acts of sacrifice by soldiers. However, Royden admitted later in life, that as the war progressed she became increasingly uneasy about her commitment to this position.

When Japan invaded China in I93 I Royden witnessed the impotence of the peace movement in responding to gross violations of international law and the tenets of the League of Nations, which held so much promise for her as an arbitrator of international disputes. She and other pacifist leaders proposed the creation of an international peace army, which would travel to China and interpose itself between the battling forces. Despite enormous publicity the call for volunteers elicited only one thousand willing participants. Royden was deeply crushed by the poor response from her 
pacifist colleagues. She came to believe that "the real emptiness of pacifism is shown by its absence of any constructive policy in the least equalling the heroism that is poured into the destructive necessities of war." ${ }^{18} \mathrm{By}$ the time of the Munich Agreement in 1938 Royden no longer advocated pacifist restraint in the face of military aggression. This renunciation of her former position generated strong commentary from those who admired her courage as well as from those who felt she had betrayed the movement. One of her contemporaries, Vera Brittain, speculated that Royden's vascillation may have been due to her pragmatic political background. ${ }^{19}$

Royden did remain loyal to the peace movement, for in 1936 she left her work with the Fellowship Guild to devote all of her time to an Emergency Peace Campaign, which brought her to the United States. Royden had already visited the United States on several occasions ${ }^{20}$ and was considered a controversial figure- not entirely on account of her political views. During her tours in the late I920's speaking engagements in New York, Boston and Chicago had to be cancelled due to public disapproval of her cigarette smoking. Letters denouncing Royden's "unclean," "un-Christian habit" flooded newspapers in areas where she spoke. Nevertheless, with each visit Royden's American following grew to the extent that in 1937 one magazine described her and the more flamboyant Aimee Semple McPherson as "rivals for the title of world's foremost woman preacher." 21

At the age of sixty-five Royden undertook her fourth and final peace journey to the United States with the Second World War already in progress. After the death of the Reverend Hudson Shaw's wife in I 944 Royden married the eighty-five-year-old minister, who survived only two more months. The remaining years of her life were spent in relative solitude. Royden died at her home in I 956 leaving behind a legacy of sermons which had comforted a generation by extolling the human spirit during times of great inhumanity. To our benefit and through the diligence of $\mathrm{J}$. B. Kaiser this material survives as a source of continuing inspiration.

${ }^{18}$ AMR, "The Failure of the Pacifists," Survey Graphic, Dec. I94 I, pp. 68 I, 7 I 4.

19 Martin Ceadel, Pacifism in Britain 1914-1945: The Defining of a Faith (Oxford: Clarendon Press, I980), p. 94.

${ }_{20}$ In March of 1928 Royden stayed at the home of J. B. Kaiser and his family while she was in Oakland, California to deliver an address sponsored by the Oakland Forum of the League of Women Voters.

${ }_{21}$ “Aimee's Rival," Literary Digest, March 20, 1937, p. 32. 